\title{
The Problems and Countermeasures of the Development of Internet Finance in China
}

\author{
Liu Zhangfa ${ }^{1}$ and Tao Yongchao ${ }^{2}$ \\ ${ }^{1}$ Dongchang College of Liaocheng University \\ ${ }^{2}$ Shandong Academy of Social Sciences
}

\begin{abstract}
Keywords: Internet finance; Traditional financial institutions; Financial disintermediation; Finance
\end{abstract} innovation

\begin{abstract}
As a beneficial supplement to our financial system, the development of Internet finance has promoted the innovation of financial model and injected strong vitality into financial market. Internet finance provide clients with more convenient and fast financial services, effectively alleviate the financial exclusion, reduces the information asymmetry. It is of great significance to promote the marketization of interest rate and promote the development of inclusive finance. At the same time, Internet finance also has problems such as lack of supervision, lack of risk prevention and control, lack of perfect credit system and credit evaluation mechanism etc. The Internet finance has caused a certain impact on traditional financial business, and weakened the traditional financial industry's dominant position. We need to take effective measures to improve risk management, promote business innovation, strengthen communication and cooperation with traditional financial institutions, promote the healthy development of China's Internet finance industry.
\end{abstract}

\section{Introduction}

With the continuous improvement of Internet information technology, Internet financial innovation business has developed rapidly. Internet finance has broken the business model of traditional financial institutions, and has been growing in ways such as third-party payment platforms, P2P network loans, online financing and crowd-funding。 Internet finances rely on Internet, big data and cloud computing technology, pay attention to the customer experience of interactive, enhance the convenience of the small and medium-sized enterprise financing, bring small customers more financing options, meet the individualized and inclusive financial demand, improve the efficiency of financial resources allocation. On the other hand, the high leverage characteristics of Internet finance make risk communication more extensive, which has a certain negative impact on the stability of China's financial system. In addition, Internet finance has impacted traditional financial business to some extent, so it is necessary to take necessary intervention to prevent potential risks. Under the background of the gradual promotion of financial disintermediation and interest rate marketization, Traditional Banks should change their business philosophy in time, constantly innovate financial services, strengthen cooperation with Internet enterprises, and finally achieve mutual benefit and win-win situation.

\section{Current Situation of Internet Finance Development}

Internet finance is a new model of various forms of financial business which non-financial institutions can realize financing, payment, resource allocation and information intermediary through cloud computing, big data, Internet technology and mobile communication technology. As an emerging field combining traditional financial industry with Internet technology, Internet finance provides customers with more convenient and fast financial services, effectively alleviate the financial exclusion, reduces the information asymmetry, promote the marketization of interest rate in our country. It is of great significance to promote the development of inclusive finance. At present, according to different business models, Internet finance is mainly divided into third-party payment, P2P lending, crowdfunding and Internet financing. Internet finance has the characteristics of low transaction cost, convenient payment, high transparency and high risk. Internet financial 
enterprises integrate market data through cloud computing, big data analysis and other technologies to carry out capital risk assessment, which is conducive to reducing the market information asymmetry between the supply and demand of funds. Customers can transfer and pay through smart phones, breaking regional and time constraints and improve the efficiency of financial transactions. However, compared with the traditional commercial Banks, financial risk control ability is insufficient,

The problems such as payment risk, transaction risk, network security risk and default risk are outstanding, lack of complete credit evaluation system and lack of necessary legal supervision and coordination mechanism.

Third party payment

Third party payment is the earliest Internet financial model. It is the trading support platform provided by the third-party independent institutions contracted with the national and foreign Banks with a certain strength and credibility, with the help of advanced information technology, docking the bank to pay the clearing interface and helping customers to complete payment and settlement. Third party payment can reduce the risk that the buyer will not pay the goods and the seller will not deliver the goods, and can enhance the credit of both buyers and sellers. In 2010, the people's bank of China promulgated the "administrative measures on payment services for non-financial institutions" and " Implementation details of management measures for non-financial institutions' payment services (Exposure Draft) Third-party payment is legally incorporated into the national regulatory system. In recent years, third-party payment has been developing rapidly in China. The network settlement mode such as alipay, tenpay and WeChat has the characteristics of low transaction threshold, convenient payment and great market potential.

\section{P2P Lending}

$\mathrm{P} 2 \mathrm{P}$ online lending is an Internet platform built by network credit companies as information intermediary and transaction intermediary, to promote the financing of both sides, the two sides freely bid for the transaction, network credit companies to collect intermediary service fees. The $\mathrm{P} 2 \mathrm{P}$ lending platforms mainly include a one-to-one guarantee mode represented by lu jin, a one-to-many online mode represented by renren, and a multi-mode debt transfer mode represented by yixin.

Internet lending companies understand the credit status of the financiers through the big data on the internet, then carry out risk assessment to build a bridge between supply and demand, to help individuals and small and medium-sized enterprises to solve financing problems.

In 2014, China merchants bank launched the investment and financing business of the e-family of small enterprises, which marked the official launch of the P2P lending platform of China's commercial Banks. At present, a number of Banks have been engaged in business cooperation with alipay, tianye payment and other institutions.

Crowd-Funding

Crowdfunding is a new financing model for investors to raise project funds through the Internet. Because of lack of fund, small companies or creative individuals publish their projects on crowdfunding platforms to show creativity and demand.Investors buy products or ideas through group-buying or pre-purchasing to provide project funds, and eventually investors are paid back in kind, work, service or media content. According to the project return mode, crowdfunding mode is divided into equity-based crowdfunding, reward crowdfunding, public welfare crowdfunding and debt crowdfunding. It is characterized by low threshold, low cost, simple and transparent process, relatively small amount of fundraising, and no need to rely on personal network resources and pay more attention to project creativity.

Compared with traditional financing methods, public financing is more open, and don't take project commercial value as the sole criterion

internet financing

Internet financing means that investors purchase wealth management products issued by fund management companies, trust companies and other financial institutions through Internet platforms, finally realizing capital appreciation. The Internet wealth management platform uses the long tail 
effect to concentrate the scattered funds into the market, so that investors can Investors get high returns on low participation costs.In 2015, Yuebao topped the list of the top five Internet financial products in China. Yuebao is a value-added service created for individual users by Alipay. sers can transfer the funds of Yuebao at any time to online shopping, alipay transfer, etc., without any fees. In June 2013, alipay network company launched yu 'ebao business with tianhong foundation.

Generally speaking, Internet finance uses information technology such as Internet, big data and cloud computing to collect, identify and process massive unstructured data, and analyze the customer's consumption characteristics in real time and accurately predict the behavior of customers to meet the personalized needs of customers. Today, big data plays an increasingly important role in the financial industry, it can help financial institutions filter through massive amounts of data, and accurately predict customer behavior and reduce information asymmetry, promote financial services, reduce costs, and control transaction risks. Ali small loan is the use of big data processing method to evaluate the credit situation of customers more accurately, and reduce the risk of credit management and improve the financing efficiency of small and micro enterprises.

\section{The Impact of Internet Finance}

The promotion of Internet finance business to traditional financial industry.

The development of Internet finance promotes the innovation of financial model. Compared with traditional financial institutions, financial operations do not need to open numerous branches and entities outlets, changing the traditional way of trading, which can reduce the cost to a great extent, save human resources, and improve transaction efficiency. The development of Internet finance promotes the innovation of traditional financial business and promotes the reform of commercial Banks. Internet finance has advanced information processing technology and convenient and fast personalized service, which provides timely and effective financial support for entrepreneurs and small and medium-sized enterprises. Influenced by the successful launch of P2P lending, crowdfunding and internet financing, Commercial Banks have also gradually relaxed the small and micro lending business, increasing the selection of high-yielding wealth management products, focusing on interactive customer experience and improve customer satisfaction.

Internet finance is a useful complement to China's financial system and has injected great vitality into the financial market. Internet financial platforms such as mobile payment are convenient and fast, which brings great convenience to customers and meets the personalized needs of customers. The huge user information database makes Internet finance business have rich information advantages. Resource sharing improves the transparency of financial services and reduces the problem of information asymmetry.

The negative impact of Internet finance on traditional financial industry.

Internet finance itself has problems such as lack of supervision, lack of risk prevention and control, lack of perfect Internet credit system and credit evaluation mechanism. Virtual Internet finance increases the transaction credit risk, financial security problems, users' personal trading information disclosure, virus invasion, the network paralysis, financial fraud, which is a serious threat to the customer's information security system. In addition, China's laws and regulations on Internet financial regulation still need to be improved. Internet financial payment risk, default risk and other potential risks are existing in internal finance. Therefore, it is necessary to strictly regulate the access system of Internet market, regulate business operation, and define the rights and obligations of both parties, so as to ensure the rapid and healthy development of Internet finance.

The rapid development of Internet finance has caused a certain impact on the traditional financial business and weakened the dominant position of the traditional financial industry. First of all, traditional financial institutions mainly profit from the difference of deposit and loan, and the rapid development of Internet financial innovation has diverted funds from traditional financial industry and affected the deposit and loan business of commercial Banks. Secondly, the development of Internet finance accelerated financial disintermediation and weakened the intermediary function of traditional financial institutions. Thirdly, the low threshold of Internet financial platform can attract social idle funds and divert funds from traditional financial institutions to influence traditional 
financial deposit and loan business.

\section{Countermeasures and Suggestions for Promoting the Development of China's Internet Financial Industry}

With the continuous improvement of Internet technology, the Internet financial innovation business is booming. The advantages of Internet finance and traditional financial institutions should be recognized correctly. Traditional commercial Banks have abundant capital strength, rich customer resources, advanced software and hardware facilities, complete risk identification and risk control systems, and strict financial supervision, has a large number of finance computer, management and other professional talents, providing professional consulting, investment plan and other services for commercial Banks. However, Internet finance has characteristics of high leverage, and the risk spread is faster and more extensive, which has a negative impact on the stability of China's financial to some extent. Therefore, both of the two should learn from each other, integrate and strengthen cooperation to promote the healthy development of the whole financial system in our country.

Improve risk management and pay attention to network security.

In order to promote the healthy development of Internet finance industry, we should establish and improve the coordinating mechanism of Internet financial regulation as soon as possible, and promote the Internet financial information disclosure mechanism, strengthen the construction of Internet financial credit system, make the Internet financial enterprises get the necessary financial regulation, win public trust in Internet finance. Internet financial enterprises should pay more attention to industry self-discipline, strengthen security construction, ensure network security, and guarantee investors' information and financial security. At the same time, the supervision department should fully respect the law of the development of Internet finance, and respect the pioneering and innovative spirit of Internet finance practitioners. Let the market play a decisive role in the allocation of financial resources, guide and support the Internet financial institutions through the form of industry self-discipline and perfect management, Integrity based, law-abiding management

Promote innovation of Internet finance.

Internet finance should innovate business constantly, simplify the process, and build a perfect online interactive system to meet the personalized needs of customers. The Internet financial platform should break regional restrictions, expand information access channels, innovate business models and financial products constantly to provide customers with better products and services. Internet financial enterprises have obvious advantages in information technology. With the help of Internet technology, e-commerce platform, social network and other technologies to process and integrate data, it is able to analyze customer's potential needs and enhance information transparency. Financial enterprises should make full use of the Internet information resources and advantage of big data to improve business ability, reduce the transaction risk, strengthen the communication with customers, introduce personalized and diversified financial products continuously.

Strengthen exchanges and cooperation with traditional financial institutions.

After years of construction, the traditional financial institutions already had a large-scale professional talents team, a complete mechanism management mode, a better risk prevention and control system and a good credit system. Internet financial institutions should learn to introduce the management mode of traditional financial industries such as Banks, to increase safety construction, and strengthen business exchanges with traditional financial institutions and deepen business cooperation with insurance companies and major Banks, form complementary advantages and improve their own credit rating, promote cooperative development and win-win cooperation. At the same time, traditional financial institutions should have open and interactive mentality and thinking, and seek the maximum intersection between Internet finance and traditional financial institutions. Banks can draw on the advantages of Internet finance, promote their own business network, and pay more attention to the accumulation of customer information resources, To improve customer information database, use Internet and other technologies to position customers' characteristics accurately, process user experience feedback timely, tap potential customers' 
demands, and develop customer resources.

\section{Reference}

$\mathrm{Xu}$ rongzhen, Yin yuanxing, Wang shuai. The operation mode and risk control thinking of P2P online lending platform -- based on information asymmetry[J]. The finance and accounting monthly, 2017(5).

Zhao dan, Zhang hongying. The construction of Internet financial audit supervision system and its realizing path. [J]. The finance and accounting monthly, 2015(25).

Chen xiao fang, Deng yinhua. "Internet finance and finance lease." SWOT analysis of the A2P model[J]. The finance and accounting monthly, 2017(2). 